\title{
Impact Study of DAAI TV Humanistic Broadcasting: Stories of Two Families
}

\author{
Rahma Widayanti Mandasari \\ Universitas Islam Negeri Sumatera Utara, William Iskandar No V, Deli Serdang,20361 , Indonesia \\ E-mail :rahmamamdasari21@gmail.com
}

\begin{abstract}
This study was inspired by the finding of the previous research that is related to positive impact in viewers' life after watching anti mainstream television shows. The television show is broadcasted by television channel which committed to show humanistic program which has the value of grateful, dutiful to parents as obligation, empathy for others without discrimination and caring character to environment. This research subject are loyal viewers of private television in Indonesia. The research method used is a case study where the researcher become the main instrument in conducting this research. The other instruments are field notes, observation result, documentation, and in-depth interviews. Research result shows that television channel namely DAAI TV give positive impact to viewers, such as being a grateful person, dutiful to parents, being a person who benefits other byvolunteering for the community and has the character who love environment..
\end{abstract}

Keywords-Humanistic;televisionshow;socialbehaviour

\section{INTRODUCTION}

It is undeniable that in this millennial era, broadcast media such as Television has become necessity for everyone. Nowadays Conventional Television has been developing into internet network such as you tube channel, streaming video and other applications. According to data of study conducted by Omnicom Media Group, Hearts and Science agency, 47 percent of respondents aged from 22 to 45 years prefer watching information through video. However, it does not mean they do not watch TV content at all, but they still watch their most favorite programs. Still according to the same study, it is found that less than one third respondents which include more than 1500 people prefer watching TV and videos, while the rest prefer watching videos in applications such as Roku and Apple TV. Contents of broadcast media consist of varied genres that target the audiences. Recently, many TV contents are troubling society especially mothers since they contain bad and not worth watching elements.
Evidently children are free to watch those contents since they are broadcasted at prime time. (Kottler, Modern Television Management, 2016: 49).

Television in Indonesia focus only on rating so that they ignore violent scenes, bad gangsters, hatred, adult scenes, revenge, disrespecting parents and oppressing others. Indonesia Broadcasting Commission or KPI that regulates broadcasting norms often warns some TV stations related to their unfeasible contents. As taken from $\mathrm{CNN}$ Indonesia on March $18^{\text {th }} 2016$, there are 8 TV stations that are warned by KPI:

\section{A. Dahsyat}

A musical program in which one of their guests, Zaskia Gotik insulted Pancasila as the symbol of Indonesian nation. At that time, the actress mentioned the symbol as 'squeaky duck'. Although Zaskia has apologized to the society, KPI added that her action might be sentenced 
imprisonment and fine as it is regulated in law number 24 regarding to flag, language and symbol of the nation.

B. Inbox

A musical program broadcast since 2007 performed 3 male dancers wearing 'kemben' (Javanese chest cloth). KPI considered that it would potentially give bad influence to the children since the show was broadcast at prime time. Furthermore, KPI forbid male celebrity to wear women's cloth.

C. Yuk keep smile

A comedian program which contained the violations of politeness norms both verbally and nonverbally. This show raised protest from Betawi people for showing a dog called by host as 'Benyamin syueb"who was a Betawi legendary comedian.

D. Komik Selebriti

An erotic scene of three women dancing with school students wearing their uniforms. KPI gave administrative sanction and suggest the production team to evaluate this program.

E. Bukan Empat Mata

A show hosted by Tukul Arwana presented a séance action which caused a man possessed. According KPI, this show was projected for teenager or adult and should be broadcasted at above $10 \mathrm{pm}$, yet children could watch this program which was broadcasted at $9.48 \mathrm{pm}$.

F. CCTV

A program that shows human interest in everyday life through the eye of hidden camera. There was an episode showing a man who turned on a firecracker that cause an explosion and damaged himself and leaked the underground pipe. Certainly, this uncensored part was considered by KPI as an extreme and inappropriate scene.

G. Pesbukers

The hosts of the show uttered blasphemous words that are inappropriate to the audience. Therefore KPI gave this program a written warning.

H. Wisata Malam

One of episodes showed the dark side of night life in Indonesia. There was a sexy lady who visited a church in Ambon and had an intimate chat with a man. Both of them entered the church. KPI gave them written warning for violating the politeness norms.

DAAI TV existed in 2007 and positions itself as Television of great love, broadcasted terrestrial in Jakarta and Medan. Since its attribute is great love, this TV station has inspiring and educative programs which contain moral messages and empathy. The programs reflect the values of truth, goodness and beauty. This commitment to spread these values in this global and competitive era makes DAAI TV different and exists as an 'anti - mainstream' Television compared to others. Humanist cultur values is a lifeblood for DAAI TV. This station realizes that it has a very strategic role as one of mass media in Indonesia. Therefore, all management staff and journalists carry on moral responsibility in each program they produce. Therefore, DAAI TV only broadcasts programs related with struggling stories, lessons of life, education, health, social charity, humanist culture and environmental conservation. DAAI TV believes that great things take times, great things take efforts, and great things happen when we work together.

Table. I

VISION AND MISSION OF DAAI TV

\section{VISION}

Purifying the human's hearts, lighting up the world.

MISSION

Becoming the most favorite humanist culture TV station for families.

MOTTO

Truth, Goodness, Beauty.

Truth: Presenting the real facts of life.

Goodness: Presenting positive and advantageous programs for the audience.

Beauty: Packaging the programs with aesthetics and the beauty of life.

Humanistic or humanism according to humanist magazine is a rational philosophy informed by science, inspired by art, and motivated by compassion. Affirming the dignity of each human being, it supports the maximization of individual liberty and opportunity consonant with social and planetary responsibility. It advocates the extension of participatory democracy and the expansion of the open society, standing for human rights and social justice. Free of supernaturalism, it recognizes human beings as part of nature and holds that values-be they religious, ethical, social, or political -have their source in human experience and culture. Humanism thus derives the goals of life form human need and interest rather than from theological or ideological abstractions, and asserts that humanity must take responsibility for its own destiny. While Humanist culture of DAAI TV is absorbed from Tzu Chi values. Tzu Chi is Buddhist non - profit organization founded by a Nun, named 
Master Cheng Yen in Hualien - Taiwan. In 1994 Tzu Chi was established in Indonesia. Although its principles are adopted from Buddhist teaching, Tzu Chi embraces all people under the universalism. Its volunteers consist of people with different religions and races throughout the world. The Tzu Chi humanist culture is culture of interaction to others inherited from generation to generation which deals with gratitude to God, love and care to others, filial piety, empathy, respect and preserve the nature.

Bandura (in Syamsul, 2011. Page 132-133) confirms that social behavior is the result of continuously reciprocal interaction between defining internal and external factors. The realization of internal factors are in the forms of cognition, perception, and other factors that could influence human activity. While external factor is environment itself, this process is called as 'Reciprocal Determinism' that becomes basic principle to analyze psychosocial in some complex levels, stretched from intrapersonal development, interpersonal development, interacting function of organization to social system. Therefore, Television programs could influence the social behavior either bad or good.

Problems of The study are formulated as : What are humanistic broadcastings in DAAI TV that differ them with other TV programs?

1. What are the impacts of DAAI TV humanistic broadcasting based on two viewer's experiences on their social behaviors?

2. What are the humanistic values that influence viewer's life?

\subsection{The Objectives of Study}

The objectives of this study are:

1. To describe what humanistic broadcastings are, founded in DAAI TV.

2. To describe the impacts or positive influences experienced by two viewers of DAAI TV.

3. To describe the humanistic values that influence the viewers.

\subsection{The Significances of Study}

\section{Viewers}

Viewers are expected to have positive influences in their way of life, manners and way to interact with others in everyday life. They could be good role models to inspire others to be humanist since doing good deeds could give benefits not only to others but also for ourselves.

2. Mass Media

Mass media especially Television stations could adopt DAAI TV humanist broadcasting in order to educate Indonesian society, to spread love and minimize contents which reflect violence, anarchism, impolite scenes and so on. In fact, humanist culture program still could get a place in viewer's heart.

\section{Society}

This Impact study is expected to give a reference for parents, teachers or society to choose proper programs for children, students or family members.

\section{METHOD}

Method of this study is case study. This kind of method is applied to reveal facts in the case under study, facts which reflect relevance between intensity of the viewers in watching TV and their social behavior. Yin (2003) (in Abidin , 2011. Page 209) stated that case as the object of study in case study is used to give sample lesson from treatment in certain context. Case selected in a case study must be able to show a change or difference caused by behavior towards the context being studied. By exploring the facts that become the causes of the case is expected to give new knowledge.

Subjects of this study are Nuraina Ponidjan, 52 years old, a mother of two sons, lives at Jalan Prof. HM Yamin 279 Medan. Three informants who support the data are her husband (Amir Tan) and sons (Andryan Viryadi Tanamir, 25 years old, and Jefri Viryadi Tanamir, 22 years old). Another Subject is Aini Lidjaya, 51 years old, lives at Jalan Brogjend. Katamso Komplek Perumahan Baru II 5 Medan. Three informants who support the data are her husband (Jasin), Eric Cantona (her son, 24 years old) and Jennifer (her daughter, 14 years old). The researcher observes the two subjects through informal interviews, TV Interviews (for DAAI Inspiration Program) which is broadcasted every Sunday at $6.30 \mathrm{pm}$, rerun at $10 \mathrm{pm}$ and every Monday at $8.30 \mathrm{am}$ on DAAI TV. Furthermore, the researcher also read the transcript of $\mathrm{Tv}$ interviews in a whole script form made by the reporters. The Tv Interviews are available through you tube links as follow: (https://youtu.be/-ZaDdeJB9y4).

\section{RESULTS AND DISCUSSION}

The researcher found results formulated as the problems of analysis which consist of what humanistic culture 
programs broadcasted in DAAI TV are that differ them with other TV stations, the impacts of humanist programs on social behavior of two viewers (Aini Lidjaya and Nuraina Ponidjan), and the humanist values that influence the two viewers significantly after watching DAAI TV programs. This study was conducted within two weeks through some pre - production times, production (taping) process by reporter and cameraman (Elsa Fanny Luluk and Vinson Theodoric), and transcripts in a whole text or script. There are positive impacts found in this study that are reflected in some aspects of life of the the two viewers (Aini Lidjaya and Nuraina Ponidjan. They are described in their social behaviors which consist of behavior to family, to friends or society, to parents and to the nature or environment.

\section{A. Ainy Lidjaya's story}

Social behavior of to her family: Through the intensive observation towards Aini Lidjaya and her family, it is found that according to her husband, Jasin, Aini has been changed into a very gentle and loving care wife and mother for his children. Now she is able to control her emotion and stay calm in facing troubles. A true story drama called ' Ketika Gladiol Bersemi', (When Gladiol bloom), broadcasted in DAAI TV on August $9^{\text {th }} 2005$, has inspired her to become a good mother to her children. This drama tells about life of $G a$ Family in 1940 in Cau Shan Mountain. They hold traditional values from ancestors firmly. Gao Chi $\mathrm{Yu}$, a flower farmer, served as head of the village. His father master the literature, well knowledged and wise.Gao diligently researched a species of flower named as Gladiol. He wishes to change Cao Shan Mountain into mainland of flower. This business makes his family wealthy and very respected in this area. This drama contains humanist values such as: family unity and togetherness may be a way to solve problems, harmony and supporting spirit in family, filial piety, simplicity of life and saving for future. These values of the drama have inspired Aini Lidjaya to love her family and to educate her children to be success with the spirit of philanthropy and generosity. Therefore, Aini also encourages her children to join her as Tzu Chi Volunteers. Tzu Chi itself is an International non government organization, founded by a nun, Master Cheng Yen, on May $14^{\text {th }} 1966$ in Hualien Taiwan, engaged in humanity, social charity, health, education (character building), International assistances for victims of natural disaster, community volunteer, environment conservation, that holds firmly the Universalism (across tribes, religion and nation).
Social behavior of to society: DAAI TV program called as "'Lentera Kehidupan', (the lantern of life) is spiritual motivation delivered by the founder of Tzu Chi International foundation, Master Cheng Yen. It is broadcasted everyday at $6.45 \mathrm{pm}$. Apparently this program has awakened herself to become a better person. She found out that this life must be fulfilled with doing good deeds and being a beneficial person to others. After watching that program few years ago, Ainy decided to become a volunteer for Tzu Chi. She began to search information and address of Tzu Chi branch in Medan. In 2012 she officially became a volunteer. She has been getting involved in many charity actions with Tzu Chi such as social services (cataract surgery, hernia surgery, responses to natural disaster victims), visit to leprosy patients who are abandoned by their families in Lau Simomo Leprosy hospital in Kabanjahe North Sumatera. Ainy feels a true happiness when she is able to help others.

Social behavior of to Parents: There is a word of contemplation or called as Jing Si Aphorism which is frequently delivered by Master Cheng Yen in ''Lentera Kehidupan', (life wisdom) program, that "there are two things that cannot be delayed in this life: filial piety and doing virtues"'. These values are frequently used as central theme of her teachings and her books as well. Filial piety has been a valued virtue in Chinese culture, yet it is being forgotten in modern society like nowadays. Seeing children who cause their parents to worry by living recklessly and adults who send their aged parents off to nursing homes and ignore them, Master Cheng Yen emphasizes filial piety as a key virtue that is necessary to be revived today, just as it was in the past. While this concept of filial piety seems foreign from a Western perspective, it can be understood as an extension of "'honor your father and mother." To be filial, we need to start by recognizing and being grateful for the hardship and dedication that our parents have experienced in bringing us into this world and raising us into adulthood. This includes the great paint of childbirth and all the sacrifices that parents make to raise their children. So if we always keep their tremendous sacrifice and dedication in mind, we will honor and thank our parents. These values are embedded within Ainy's heart and make her honor her late parents. Therefore she educates her children to be filial and respect the elderly. She often goes to nursing home like Taman Bodhi Asri in on Jalan Bintang terang ujung number 53, Puji mulio Medan -Binjai. She gives love and care to the elderly 
and treats them like her own parents and she never agree with the idea of sending parents to nursing home.

Social Behavior of to nature/environment: All programs of DAAI TV especially which are produced in Medan such as DAAI Inspirasi (broadcasted every day at 6 every day at 6.0 pm), Bingkai Sumatera (broadcasted every Monday at $7 \mathrm{pm}$ ) and Selasar Budi talk show (broadcasted every Wednesday at $7 \mathrm{pm}$ ) reflect humanist culture which include environmental conservation mission. All topics appointed in those programs are related with environmental preservation. Interviewees of the programs are getting involved in that mission independently such as mangrove preserver, rare plants preserver, recycling agent, creative person who utilizes recycle things or wastes. Becoming a Tzu Chi volunteer, Ainy keeps on watching DAAI TV programs to strengthen her commitment in doing virtues. She also learns from those inspiring interviewees who do good deeds with their own abilities. Ainy has changed her life style to go green lifestyle. She becomes administrator of one of Tzu Chi environmental preservation depots in Medan. Every Saturday and Sunday, she spends her time to do recycling at Tzu Chi Depot in Titi Kuning district - Medan. Recycling consists of sorting out trash, papers, bottles of mineral waters, electronic things, and others. The sales of these recycled things will be allocated for the operation of DAAI TV Medan station. While in Taiwan, Tzu Chi volunteers will first clean and sort the recyclables by material. If they cannot be used again, volunteers will sell them to professional recyclers. The recyclables that can still be used, volunteers will make patchwork handbags or trinkets with clothing items that can no longer be repaired. Tzu Chi volunteers in Philippines once used 1.138 plastic bottles to make a lifeboat, while volunteers in Taiwan also made a lifeboat with Styrofoam to deliver relief supplies to people affected by flooding. Tzu Chi volunteers in Taiwan also clean and sort the Polyethylene Terephthalate or PET bottles by color before sending them to non - profit DAAI Technology to process and spin into yam, which is then woven into fabric to be made into various items of clothing as well as blankets for Tzu Chi to give out to those in need or affected by disaster. Many of the products are available for sale, with all proceeds donated to Tzu Chi. By acting as volunteer of environmental preservation mission, Ainy will not feel disgusted with trash or rubbish since there is a motto that motivates them saying "'Trash can be changed into gold, and gold can be changed into purified flow of love." Ainy is also motivated by one of words of contemplation delivered by Master Cheng Yen which says " the hand of environmental protection is the most beautiful hand" (in Kata Perenungan, 2013, article 68 page 34)

\section{B. Nuraina Ponidjan's story}

Social behavior to family: Through some intensive observations, same as Aini Lidjaya's story, Nuraina has changed into a gentle and full of love wife and mother in the eyes of her husband and two sons. She can handle her emotion and becomes wise person. Her youngest son, Jefri Viryadi Tanamir (22 years old) in an interview with DAAI TV Medan crew (DAAI Inspirasi, broadcasted on $3^{\text {rd }}$ March 2019) confessed that since her mother joined Tzu Chi foundation, Nuraina is not angry easily, her mother turns to be a more patient and calm in facing problems. These positive characters exist within herself after watching Lentera Kehidupan (life wisdom) regularly. This program contains of spiritual motivation that touches everyone to become a person with wisdom, grateful and firmness in doing virtues. For Nuraina, this program could give her solution and inspiration in facing problems of life. Some episodes that knock her heart are: Semua Orang Di Dunia bagai Satu Keluarga (everyone in this world is united in a family, broadcasted on $8^{\text {th }}$ May 2019), Giat Melatih Diri di tengah Ketidak kekalan Hidup (Train yourself in Impermanence, broadcasted on $7^{\text {th }}$ May 2019), Membina Ketulusan, ketekunan dan keyakinan teguh (Maintaning sincerity, perseverance, and strong belief, broadcasted on $6^{\text {th }}$ May 2019). 12 minutes a day, 365 days a year, the founder of International Tzu Chi foundation, Master Cheng Yen, reflects on the events happening in Taiwan and all over the world through the wisdom of Dharma (Buddhist teaching). Therefore, Nuraina is always motivated by this program to practice Dharma in her aspects of life. She also motivates her husband and sons to absorb the Dharma and spread love to others based on Tzu Chi principles. Her two sons also join her parents to become young Tzu Chi volunteers which is called as Tzu Ching.

Social Behavior to Society: The relationship mate with DAAI TV and Tzu Chi foundation started when Nuraina and her husband, Amir Tan, presented in a Tzu Chi event at the end of 2010. The couple were inspired to be Tzu Chi volunteers and getting intimate with DAAI TV humanist programs. This is how they do charity and contribute themselves to the world of humanity. Not only getting involved in some charities such as cataract social service, Sinabung eruption or other 
natural disasters service, blood donors, health service for the poor, Nuraina and Amir are also contributing themselves as the volunteers of Zhen Shan Mei (volunteers who act as journalists in carving the history and journey of Tzu Chi in bulletin, magazine and online media). Nuraina prefers to be a reporter who works with her husband as photographer. Sometimes she also acts as a camera person to record all events. According to them, it is not easy to do the journalistic duty since they realize that they have not enough competence in professional journalism. However, the strong will to do good deeds conquers the problem. They recharge themselves by watching lentera kehidupan (life wisdom) and keep one of Jing Si Aphorism delivered by Master Cheng Yen,in the program which says ' 'Grasp the opportunity to do virtues, do not wait to do that." Therefore, Nuraina and Amir Use every chance to do charity with Tzu Chi another Jing Si Aphorism that inspires them is: "Use time very well since it runs so fast." It motivates them to spend time for doing virtues not for the useless ones.

Being Tzu Chi journalist volunteer, Nuraina realizes that she has important role in motivating others to do good deeds through her journalistic works. Her works such as: "'Indahnya Kebersamaan Dalam Bersumbangsih', ("The Beauty of Togetherness in Charity,' "published on $6^{\text {th }}$ May 2019), "Menumbuhkan Cinta Kasih Lewat Donor Darah", ("'Growing love Through Blood Donor,' published on $16^{\text {th }}$ April 2019) can be seen on online Tzu Chi website.

Social Behavior to Parents: As a busy volunteer, Nuraina spends her time to do charity with Tzu Chi. She travels a lot with her husband. Nevertheless, she never forgets to give attention and love her parents who live in Kisaran city. Since her marriage, Nuraina has been living with her parents in law. She never encounters clash or conflict with parents in law. They live in harmony because she treats parents in law like her own parents. Nuraina always maintains spare times to have dinner with parents in law every Sunday night and shares her experiences in doing voluntary activity. If her parents in law need medical check - up, Nuraina and her husband will be ready to accompany them. The way how she treats parents is inspired and motivated by spiritual motivation program called as "Lentera Kehidupan', (Life wisdom) broadcasted every day in DAAI TV. Nuraina never agree with the idea of sending parents to nursing home. For her, parents are our own responsibility and we must fulfill that responsibility. She always keeps one of Jing $\mathrm{Si}$ Aphorism of Master Cheng Yen who always delivers sermons on 'Lentera Kehidupan', (Lifewisdom) program saying:

' there are two things that cannot be delayed in this life: filial piety and doing virtues." Nuraina also teaches this filial piety value to her two sons and she is convinced that her two children will not send her to nursing home in the future. Therefore, Nuraina also practices this value to other parents whenever she get involves in Tzu Chi charities especially visiting nursing home.

Social Behavior to Nature/Environment: Before joining Tzu Chi Foundation, Nuraina and her family had a bad habit. They used to throw away trash in the car or even through the window of car while driving. After joining Tzu Chi foundation and watching DAAI TV programs such as Daai Inspirasi, Selasar Budi talk show, Bingkai Sumatera in which events or recycle activities are campaigned, Nuraina realizes that this earth where we stand is not a trash can. Moreover, as volunteer, she always gets involve in recycle activity at Tzu Chi green points in Medan. Now she changes her way of life into go green lifestyle. She provides trash can in the car, organic and non organic trash cans in her home. Every day she collects recyclable waste and sends them to Tzu Chi green point. She sees trash as gold which can be turned into pure love as she know very well that the selling of Trash at Tzu Chi green point will be returned to support the operational cost of DAAI TV.

\section{CONCLUSION}

Based on the analysis of impact study of DAAI TV humanistic broadcasting: stories of two families (Aini lidjaya and Nuraina). Both Aini Lidjaya and Nuraina get positive impact on their life. They become individual who can manage emotion, serve their parents with filial piety principle, they are called to be volunteers through Tzu Chi foundation, and they have environmentally conscious behavior. These humanistic values are absorbed from watching DAAI TV programs that contain humanistic culture. The most inspiring programs for Aini Lidjaya and Nuraina are 'Lentera Kehidupan' (Life Wisdom), and true story drama ' Ketika Gladiol Bersemi', (drama contain about filial piety, respect others, patience, struggle, empathy. Not only getting benefits for themselves, they also spreading these humanistic values to their children, spouses and other people by becoming Tzu Chi Volunteers. 
The writer would like to suggest $\mathrm{Tv}$ viewers especially mothers to be more selective in choosing channel for children. It is suggested that mothers choose Tv programs which contain humanistic values that may give positive impact. DAAI Tv consistently broadcasts nonviolent and improper scenes that it may be a suitable channel for family.

\section{REFERENCE}

[1] Abidin, Y. (2011). Penelitian Pendidikan dalam Gamintan Pendidikan Dasar dan PAUD. Bandung: Rizqi Press.

[2] Cheng Yen, Shih. (2016). Buku Saku Kata Perenungan (9 ed.). Cetakan ke 1. Jakarta: Yayasan Buddha Tzu Chi Indonesia.

[3] Cheng Yen, Shih. (2018). Mirror of the Heart: The Power of Mindfulness. Taiwan: Jing Si Publishing Co., Ltd.

[4] Desmita. (2012). Psikologi Perkembangan. Bandung: PT. Remaja Rosdakarya.

[5] Hurlock, B. H. (1980). Psikologi Perkembangan: Suatu Pendekatan Sepanjang Rentang Kehidupan (5 ed.). Jakarta: Erlangga. 